\title{
KEPUASAN IBU HAMIL TERHADAP KUALITAS BIDAN DALAM MEMBERIKAN PELAYANAN ANTE NATAL CARE DI DESA SOKARAJA LOR KECAMATAN SOKARAJA KABUPATEN BANYUMAS
}

\author{
Citra Hadi Kurniati ${ }^{1}$ \\ Email : citrahadi85@gmail.com \\ Kebidanan DIII FIKES Universitas Muhammadiyah Purwokerto \\ Jalan Soepardjo Rustam Km 7 Sokaraja Purwokerto \\ Telp (0281)63751
}

\begin{abstract}
ABSTRAK
Pendahuluan Antenatal care (ANC) merupakan pemeriksaan kehamilan yang dilakukan oleh bidan. Pemeriksaan ANC sangat penting untuk mendeteksi normal dan tidaknya suatu kehamilan. Pemeriksaan ini berlangsung minimal 4 kali dalam kehamilan. Keramahan dan ketrampilan bidan dalam memberikan pelayanan ANC dapat mempengaruhi kepuasan pasien dan ketersediaannya untuk kembali ke fasilitas kesehatan untuk mendapatkan pelayanan berikutnya pada saat melakukan pemeriksaan ANC.

Tujuan Penelitian Mengetahui kepuasan ibu hamil terhadap kualitas bidan dalam memberikan pelayanan Ante Natal Care di Desa Sokaraja Lor Kecamatan Sokaraja Kabupaten Banyumas

Metode Penelitian Penelitian analitik observasional, dimana peneliti diarahkan untuk menjelaskan suatu keadaan atau situasi. Pendekatan waktu yang digunakan adalah cross sectional. Analisis dilakukan untuk menguji kepuasan ibu hamil terhadap kualitas bidan dalam memberikan pelayanan ANC. Analisis data dalam penelitian dengan variabel berskala ordinal. Pengujian hipotesis mengunakan Uji Chi Square. Hasil penelitian menunjukkan bahwa ada hubungan antara kepuasan ibu hamil terhadap kualitas bidan dengan nilai $p$ valeu < 0,05 dengan $\mathrm{X}^{2}$ hitung sebesar 21,773. Kesimpulan terdapat hubungan antara tingkat kepuasan ibu hamil terhadap kualitas bidan dalam memberikan pelayanan ANC
\end{abstract}

Kata Kunci : Kepuasan dan kualitas bidan

\section{Pendahuluan}

Rencana pembangunan jangka panjang bidang kesehatan menyatakan bahwa dalam rangka mewujudkan sumber daya manusia yang berkualitas dan berdaya saing, maka program kesehatan dilakukan bersama-sama dengan pendidikan. Pembangunan kesehatan merupakan investasi, karena telah berhasil meningkatkan derajat kesehatan masyarakat secara bermakna. Derajat kesehatan masyarakat telah menunjukan perbaikan, salah satunya dapat dilihat dari penurunan Angka Kematian Ibu (AKI) dan Angka Kematian Bayi (AKB). Meningkatkan derajat kesehatan masyarakat melalui peningkatan akses terhadap pelayanan kesehatan yang mencakup meningkatnya umur harapan hidup, menurunnya AKI, AKB, dan menurunnya prevalensi gizi kurang pada balita terkait dengan masalah AKI dan AKB. ${ }^{1}$

Sebagai upaya untuk menurunkan AKI dan AKB, Departemen Kesehatan mengeluarkan kebijakan yang mengacu kepada intervensi strategi dalam Safe Motherhood yang dinyatakan sebagai empat pilar yaitu Keluarga Berencana,
Pelayanan Antenatal, Persalinan Bersih dan Aman dan Pelayanan Obstetri Esensial. Upaya menerapkan Safe Motherhood memerlukan pelayanan Antenatal Care (ANC) yang berkualitas dan sesuai dengan kuantitasnya. ${ }^{2}$

Kepuasan pasien sering dipandang sebagai suatu komponen yang penting dalam pelayanan kesehatan. Keramahan dan kenikmatan berkaitan dengan pelayanan kesehatan yang tidak berhubungan langsung dengan klinis dapat mempengaruhi kepuasan pasien dan ketersediaannya untuk kembali ke fasilitas kesehatan untuk mendapatkan pelayanan berikutnya. Kepuasan pasien sangat ditentukan oleh ketrampilan fisik (tangible), kemampuan (reliability), ketanggapan, kepastian (assurance) serta perhatian (empathy) petugas dalam memberikan pelayanan kepada pasien. ${ }^{3}$

Peran bidan antara lain meningkatkan cakupan kunjungan pertama ibu hamil (K1), kunjungan keempat ibu hamil (K4) dan semua persalinan harus ditolong oleh tenaga kesehatan terlatih. Semua komplikasi obstetrik mendapat pelayanan rujukan yang adekuat, semua perempuan dalam 
usia reproduksi mendapatkan akses pencegahan dan pelaksanaan kehamilan yang tidak diinginkan atau aborsi yang tidak aman. ${ }^{4}$

Pelayanan kesehatan ibu meliputi pelayanan kesehatan antenatal, pertolongan persalinan dan pelayanan kesehatan nifas. Cakupan pelayanan antenatal dapat dipantau melalui pelayanan kunjungan baru ibu hamil (K1) untuk melihat akses dan pelayanan kesehatan ibu hamil sesuai standar paling sedikit empat kali (K4) dengan distribusi pemberian pelayanan yang dianjurkan adalah minimal satu kali pada triwulan pertama, satu kali pada triwulan kedua dan dua kali pada triwulan ketiga umur kehamilan. ${ }^{4}$

Tinggi rendahnya cakupan K1 dan K4 menggambarkan perilaku kunjungan ibu hamil. Lauren Green, mengatakan bahwa faktor yang mempengaruhi perubahan perilaku meliputi tiga faktor yaitu: faktor yang mempermudah (predisposing factor), yang mencakup pengetahuan, sikap; faktor yang mendukung (enabling factor )yaitu jarak dengan fasilitas kesehatan, keterpaparan media; dan factor pendorong (reinforcing factors) yaitu dukungan petugas kesehatan, keluarga dan masyarakat. $^{5}$

Rendahnya pengetahuan ibu hamil tentang perawatan kehamilan dapat disebabkan karena kurangnya informasi yang diberikan oleh bidan pada saat pelayanan antenatal. Hal ini dinyatakan oleh pendapat ibu hamil menunjukkan bahwa mereka masih sangat jarang bahkan tidak pernah melihat penjelasan dari bidan tentang jenis, urutan dan waktu pelayanan kehamilan, gizi dan pentinganya pemeriksaan kehamilan, perawatan jalan lahir, senam kebugaran, makanan untuk meningkatkan produksi.

Pelayanan kesehatan pada ibu hamil tidak dapat dipisahkan dengan pelayanan persalinan, pelayanan nifas dan pelayanan kesehatan bayi baru lahir. Kualitas pelayanan antenatal yang diberikan akan mempengaruhi kesehatan ibu hamil dan janinnya, ibu bersalin dan bayi baru lahir serta ibu nifas. Dalam pelayanan antenatal terpadu, tenaga kesehatan harus dapat memastikan bahwa kehamilan berlangsung normal, mampu mendeteksi dini masalah dan penyakit yang dialami ibu hamil, melakukan intervensi secara adekuat sehingga ibu hamil siap untuk menjalani persalinan normal.

Setiap kehamilan, dalam perkembangannya mempunyai risiko mengalami penyulit atau komplikasi. Oleh karena itu, pelayanan antenatal harus dilakukan secara rutin, sesuai standar dan terpadu untuk pelayanan antenatal yang berkualitas. Pelayanan antenatal terpadu dan berkualitas secara keseluruhan meliputi memberikan pelayanan dan konseling kesehatan termasuk gizi agar kehamilan berlangsung sehat, melakukan deteksi dini masalah, penyakit dan penyulit/komplikasi kehamilan, menyiapkan persalinan yang bersih dan aman, merencanakan antisipasi dan persiapan dini untuk melakukan rujukan jika terjadi penyulit/komplikasi, melakukan penatalaksanaan kasus serta rujukan cepat dan tepat. ${ }^{2}$

Pasien merupakan salah satu konsumen penting yang memiliki kebutuhan dan harapan. Untuk mencapainya dibutuhkan komunikasi yang efektif antara penyedia layanan dengan konsumen. Pelayanan tidak dapat berjalan efektif tanpa mempertimbangkan ketersediaan sumber daya. Jika sumberdaya tidak diperhitungakan maka mutu tidak akan tercapai. ${ }^{7}$

Umumnya fasilitas layanan kesehatan milik pemerintah kurang/ tidak dimanfaatkan oleh masyarakat. Salah satu penyebabnya adalah bahwa umumnya mutu layanan kesehatan yang diselenggarakan oleh fasilitas layanan kesehatan milik pemerintah masih belum atau tidak memenuhi harapan pasien dan atau masyarkat. ${ }^{7}$

Berdasarkan uraian latar belakang diatas maka peneliti akan melakukan penelitian dengan judul "Persepsi dan Kepuasan Ibu Hamil Terhadap Kualitas Bidan dalam Memberikan Pelayanan Ante Natal Care di Desa Sokaraja Lor Kecamatan Sokaraja Kabupaten Banyumas?". 
2. Metode Penelitian

Penelitian menggunakan analitik observasional, dimana peneliti diarahkan untuk menjelaskan suatu keadaan atau situasi. Pendekatan waktu yang digunakan adalah cross sectional yaitu penelitian untuk mempelajari dinamika korelasi antara variabel dependen dan independen serta pengumpulan data dilakukan sekaligus dalam waktu yang bersamaan dan pengukurannya hanya dilakukan sekali saja. ${ }^{8}$

Populasi dalam penelitian ini adalah seluruh ibu hamil yang ada di puskesmas sokaraja . Sampel dalam penelitian ini adalah ibu hamil yang di desa sokaraja lor, teknik pengambilan sampelnya adalah dengan menggunakan teknik accidental sampling yaitu pengambilan sampel yang dilaksanakan dalam waktu tertentu. Analisis menggunakan chi Square $\left(X^{2}\right)$ untuk mengetahui hubungan antara variabel dependen dan independent dengan menggunakan tingkat kepercayaan 95\%. ${ }^{9}$

\section{Hasil dan Pembahasan}

a. Hasil

Analisis univariat yaitu untuk memperoleh gambaran distribusi frekuensi dan presentasi dari variabel yang diteliti baik variabel independen maupun variabel dependen yang meliputi kepuasan ibu hamil dan kualitas bidan dalam pemeriksaan ANC.

\section{Gambar 1 Diagram Distribusi Kepuasan Ibu Hamil}

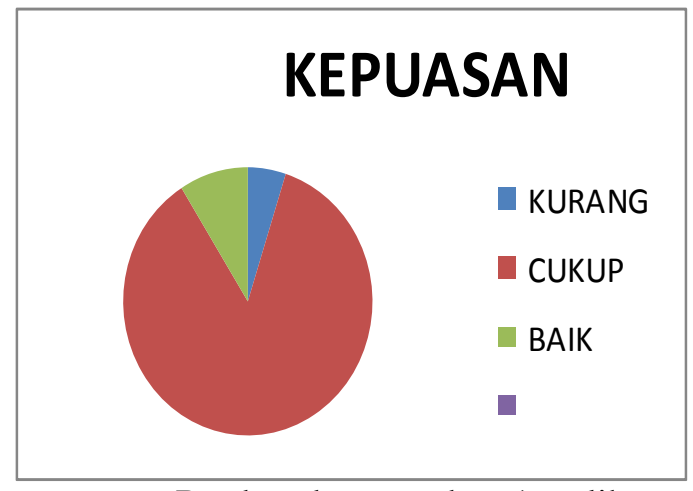

Berdasarkan gambar 1 terlihat bahwa ibu hamil yang mempunyai tingkat kepuasan yang puas (baik) sebanyak 5 orang atau sekitar $8,7 \%$, kemudian ibu hamil yang tingkat kepuasanya cukup sebanyak 49 orang atau sekitar 85,9 \%, dan ibu hamil yang mempunyai tingkat kepuasan kurang sebanyak 3 orang atau sekitar $5,2 \%$.

Gambar 2 Diagram Distribusi Kualitas Pelayanan

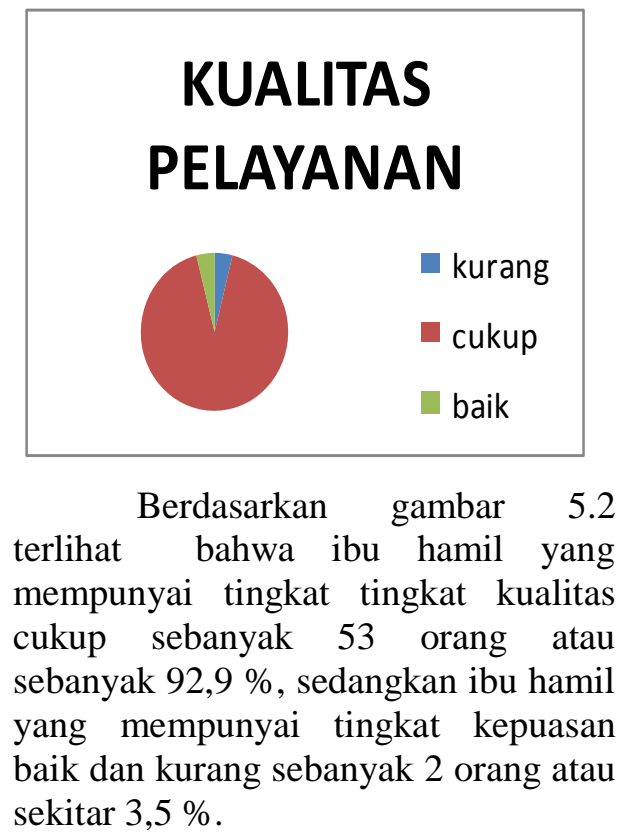

Analisis bivariat dimaksudkan untuk mengetahui pengaruh masingmasing variabel independen dan dependen. Pengujian analisis bivariat dilakukan dengan menggunakan uji chi-square secara terperinci dapat dilihat sebagai berikut :

Tabel 2 Hubungan Kepuasan Pasien Dengan Kualitas Pelayanan Bidan Di Desa Sokaraja Lor Kec. Sokaraja

\begin{tabular}{ccccc}
\hline \multirow{2}{*}{ No } & \multirow{2}{*}{ Kepuasan } & \multicolumn{3}{c}{ Kualitas Pelayanan } \\
\cline { 3 - 5 } & & Baik & Cukup & Kurang \\
\hline 1. & Baik & 2 & 3 & 0 \\
\hline 2. & Cukup & 0 & 47 & 2 \\
\hline 3. & Kurang & 0 & 3 & 0 \\
\hline \multicolumn{2}{c}{ Jumlah } & 2 & 53 & 2 \\
\hline \multicolumn{2}{c}{$\mathbf{X}^{\mathbf{2}}$} & \multicolumn{3}{c}{$21,773^{\mathrm{a}}$} \\
\hline \multicolumn{2}{c}{$\boldsymbol{P}$ Value } & & 0,000 \\
\hline
\end{tabular}

b. Pembahasan

Berdasarkan hasil analisis univariat menunjukan bahwa tingkat kepuasan ibu hamil 8,7 \% puas, 85,9 \% cukup dan 5,2\% kurang. Hasil uji statistic dengan 
chi-square menunjukan probabilitas (p) lebih kecil dari $\alpha(0,000<0,05)$. Hal ini menunjukan adanya pengaruh kepuasan ibu hamil terhadap kualitas bidan dalam memberikan palayanan ANC.

Kepuasan atau ketidakpuasan merupakan respon pelanggan sebagai hasil dan evaluasi ketidaksesuaian kinerja / tindakan yang dirasakan sebagai akibat dari tidak terpenuhinya harapan. Tingkat kepuasan merupakan fungsi dari perbedaan antara kinerja yang dirasakan dengan harapan, apabila kinerja di bawah harapan maka pelanggan akan kecewa. 10

Pada dasarnya harapan klien adalah perkiraan atau keyakinan klien tertang pelayanan yang diterimanya akan memenuhi harapannya. Sedangkan hasil kinerja akan dipersepsikan oleh klien. Kesimpulan yang dapat diambil dari beberapa pengertian di atas terdapat kesamaan pandangan bahwa kepuasan pelanggan/klien merupakan ungkapan perasaan puas apabila menerima kenyataan / pengalaman pelayanan memenuhi harapan klien. Kepuasan pelanggan adalah indikator utama dari standar suatu fasilitas kesehatan dan merupakan suatu ukuran mutu pelayanan kepuasan pelanggan yang rendah akan berdampak terhadap jumlah kunjungan yang akan mempengaruhi provitabilitas fasilitas kesehatan tersebut, sedangkan sikap karyawan terhadap pelanggan juga akan berdampak terhadap kepuasan pelanggan dimana kebutuhan pelanggan dari waktu ke waktu akan meningkat, begitu pula tuntutannya akan mutu pelayanan yang diberikan. 11

Berdasarkan analisis univariat menuunjukan bahwa ibu hamil yang mempunyai tingkat tingkat kualitas cukup sebanyak 53 orang atau sebanyak 92,9 \%, sedangkan ibu hamil yang mempunyai tingkat kepuasan baik dan kurang sebanyak 2 orang atau sekitar 3,5\%.

Pelayanan umum baru dapat dikatakan berkualitas jika sesuai dengan harapan/keinginan atau kebutuhan penerima layanan, untuk dapat mengetahui apakah pelayanan umum yang diberikan pemerintah sesuai dengan keinginan atau kebutuhan masyarakat sebagai pengguna layanan, maka kualitas pelayanan umum harus diukur dan dinilai oleh masyarakat pengguna layanan. Hal tersebut sesuai dengan pendapat Lukman dan Sugiyanto, yang menyatakan bahwa: "Kualitas pelayanan berhasil dibangun, apabila pelayanan yang diberikan kepada pelanggan mendapatkan pengakuan dari pihak-pihak yang dilayani.

Pengakuan terhadap keprimaan sebuah pelayanan, bukan datang dari aparatur yang memberikan pelayanan, melainkan datang dari pengguna jasa layanan. Hal senada pun diungkapkan oleh Tjiptono, yang menyebutkan bahwa: "Citra kualitas yang baik bukanlah berdasarkan sudut pandang atau persepsi penyedia jasa, melainkan berdasarkan sudut pandang atau persepsi pelanggan. Pelangganlah yang mengkonsumsi dan menikmati jasa, sehingga merekalah yang seharusnya menentukan kualitas pelayanan umum. Persepsi pelanggan terhadap kualitas jasa atau pelayanan merupakan penilaian menyeluruh atas keunggulan suatu pelayanan.10 Jadi prsoses penentuan suatu kualitas pelayanan yang diberikan merupakan penilaian dari penerima jasa berdasarkan sudut pandang dan persepsi pelanggan atas jasa pelayanan yang 
didapatkan. Persepsi penilaian pelanggan terhadap pelayanan yang diberikan merupakan penilaian menyeluruh dari suatu penilaian pelayanan yang diberikan sehingga dapat dikatakan bahwa suatu pelayanan yang berkualitas adalah pelayanan yang berdasarkan pada kepuasan pelanggan. Jika suatu kepuasan tercipta maka persepsi suatu pelayanan yang berkualitas akan tumbuh.

\section{Kesimpulan}

Berdasarkan hasil analisis hubungan persepsi dan kepuasan ibu hamil terhadap kualitas bidan dalam memberikan pelayanan Antenatal Care (ANC) di Desa Sokaraja Lor Kec. Sokaraja adalah sebagai berikut: Terdapat hubungan yang signifikan antara tingkat kepuasan ibu hamil terhadap kualitas bidan dalam meberikan pelayanan ANC dengan nilai $p$ valeu $=0,000$

\section{Daftar Pustaka}

[1] Depkes R.I,2009. Panduan pelaksanaan strategi making pregnancy safer dan child survival Jakarta

[2] Depkes. 2014. Buku Acuan Persalinan Normal. JNPK-KR: Jakarta

[3] Abdurrauf, 2000. Evaluasi kinerja instalasi gawat darurat RSU Banjar berdasarkan balanced scorecard, tesis, ugm, Yogyakarta.

[4] Mufdlilah. 2009. Prosedur Asuhan Kebidanan Ibu Hamil. Jogjakarta : Nuha Medika.

[5] Notoatmojo, S. 2010. Metodologi Penelitian Kesehatan. Jakarta: Rineka Cipta.

[6] Al- Assaf, 2009. Mutu pelayanan kesehatan perspektif internasional, kedokteran egc: Jakarta

[7] Pohan, I. 2006. Jaminan Mutu Layanan Kesehatan. Jakarta: EGC.

[8] Sugiyono.2010. Metode penelitian Kuantitatif Kualitatif dan RND. Bandung: Alfabeta

[9] Suharsimi Arikunto.2010. Prosedur Penelitian Suatu Pendekatan Praktik.Jakarta : Rineka Cipta

[10] Tjiptono. F. 2005. Service Quality and Satisfaction.Andi Offset: Yogyakarta.

[11] Notoatmodjo, S, 2007, Kesehatan Masyarakat, Rineka Cipta, Jakarta 